\title{
Interview with David H. Jonassen: Looking at the Field of Educational Technology from Radical and Multiple Perspectives
}

\author{
Ali Simsek \\ Anadolu University, Turkey
}

There are people whose names are identified with their fields. When an outsider wants to learn about the field of educational technology and enters some keywords, David H. Jonassen is perhaps one the few people whose names will appear instantly. Of course, this is not without reasons. David H. Jonassen has produced enormous amount of work addressing both major and trendy issues in the field of educational technology over the years. His name appears on some of the milestone work in our field. Moreover, I think it is not an exaggeration to say that he is an academic trend setter too.

David H. Jonassen has produced at least 37 books, 180 journal articles, 64 book chapters, 12 book reviews, 136 invited presentations, and 282 conference papers. He has supervised 27 doctoral dissertations; most of his advisees were international students. He has provided educational consultancy services in countries such as United States, Brazil, Australia, Saudi Arabia, United Kingdom, Singapore, Canada, Netherlands, and Italy. He has also been active in professional organizations like AECT, AERA, ASTD, and NSPI.

Throughout his academic career, he has received about two dozens of awards including but not limited to outstanding publication awards, distinguished development awards, outstanding practice awards, distinguished service awards, and lifetime achievement awards for excellence. Almost all of these awards were given by well-known professional organizations in the field of educational technology.

I am sure there is more about him but these are preliminary outcomes of my speedy search. Considering his milestone contributions and eye-opening discussions in our field along with the worldwide recognition he has among colleagues, we decided to interview Professor Jonassen for this issue of Contemporary Educational Technology. As usual, we conducted the interview through communication technologies in several rounds of exchanging questions, answers, and elaborations. I think the interview has a number of enlightening messages for all, particularly for young colleagues.

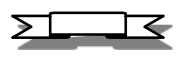

\section{When and how did you enter the field of educational technology?}

During my undergraduate studies at the University of Delaware, I worked my way through school. After two years of boring part-time jobs, I accepted a position as television cameraman producing educational television programs. I soon began repertory video and other media activities, deciding later to study for a degree in educational media. 


\section{How did the field look like then or what were the major issues/trends?}

Educational television was a major force then. Researchers were conducting media studies, and visual literacy was among the hottest issues. Media studies in education compared media such as television, with other media such as traditional face-to-face classes. The field has advanced so significantly since the 1970s.

\section{Where did you start to your academic career and how did it evolve?}

After completing a degree in finance while doing educational television production, I realized that I needed educational experience if I chose to pursue educational media. Thus, I enrolled in a certification program at the University of Delaware, after which I taught fifth grade reading and language arts and then junior high school reading and language arts. During that time, I was taking courses in learning psychology, and I decided to pursue a doctorate in educational media. While studying at Temple University in Philadelphia, I completed more courses in experimental or educational psychology than in media. My research interests have always focused first on learning and then on the technology.

\section{Which countries have you worked in and what did you do for each assignment?}

In addition to numerous international presentations, I have had visiting professorships at the University of Twente in the Netherlands, Heriot-Watt University in Scotland, National Institute of Education in Singapore, and several smaller workshop activities in Italy. In these activities, I delivered workshops, courses, and consulting on a variety of issues.

\section{How many books, chapters, and articles have you published?}

I really don't know. I believe that I have published 35 books and hundreds of articles and book chapters.

\section{Which of your publications have made the most important contribution to the field?}

That would be for others to determine. I suppose that the two editions of the Handbook of Research on Educational Communications and Technology were the largest contributions (each 1400 pages). I hope that one of my recent books, Learning to solve Problems: A Handbook for Designing Problem-Solving Learning Environments, may also be considered among my most significant contributions. It represents 15 years of research into problem solving, one of the most important yet least researched issues in education.

\section{What major areas/topics have you worked on throughout your career?}

I began early on focusing on text design, culminating on the publications of two volumes of the Technology of Text. That work is still important because so much of the information on the World Wide Web (www) is in the form of text. Also, textbooks are still prominent. While it's a topic that does not merit a lot of attention, it is still very relevant.

With the advent of microcomputers in classrooms, I gravitated toward the concept of Mindtools for students to construct models of what they know. Mindtools provide multiple formalisms for model building, each of which engages different kinds of critical, creative, and complex thinking. Mindtools include semantic organization tools (databases, semantic 
networks), dynamic modeling tools (spreadsheets, expert systems, systems modeling tools, and microworlds), information interpretation tools, visualization tools, knowledge construction tools (multimedia production, hypermedia construction and linking, Web site production), and conversation tools (synchronous communication environments, asynchronous information tools, scaffolded computer conferences). These tools can be used to build models of domain knowledge, systems, problems, experiences, and thinking processes.

\section{How do you decide to work in a particular area such as constructivism or problem solving?}

In the early 1990s, Tom Duffy and I pushed the field of instructional design and technology in a constructivist direction. With constructivism, it naturally occurred to me that I was always a constructivist so I enjoyed perturbing the field and changing minds about some of the basic assumptions of instructional design.

If you look at the topics of conference papers and articles in educational technology journals, it is obvious that we change the thinking of so many people. As indicated by the paper by Kirschner, Sweller, and Clark in 2006, some researchers believe that constructivism has little to add and that direct instruction is more effective and powerful. What is being learned from constructivist approaches to learning cannot be effectively compared to the outcomes of direct instruction so the debate is not meaningful.

During the late 1980s and early 1990s, I also examined the effects of a new technology, hypertext/hypermedia. We were examining different ways of structuring hypertext in order to facilitate learning. With the exception of Roger Azevedo, not many researchers focus explicitly on hypertext, but the World Wide Web is an example of hypermedia so it is still a relevant topic.

My interest in constructivism became instantiated in problem solving because it is probably the most constructivist form of learning. In order to learn to solve problems, learners must necessarily construct understanding of problem types and solution alternatives. While teaching instructional design at Pennsylvania State University, I discovered that there was little or no advice on how to design instruction to support problem solving. Therefore, I published the article in 1997 and just continued on that path. Once again, if you examine the titles of conference presentations and journal articles in our field, problem solving has become a much more commonly investigated topic; so one more time, I have had some impact on the field. Since the mid-1990s, I have focused most of my research on problem solving.

One of my side interests has been the role of epistemic beliefs on learning and problem solving. Epistemic beliefs describe the ways that we conceive of knowledge, learning, and authority. What is the role of the student, a receiver of information or a constructor of knowledge. Research on epistemic beliefs today still continues in the educational psychology field, and it has implications for the field of educational technology.

\section{What kinds of projects have you completed and which of them excited you the most?}

We have completed many funded projects. Perhaps the most interesting was designing a new curriculum and instructional support for radiation protection technicians working in nuclear power plants, hospitals, irradiation facilities and elsewhere. We designed case-based environments around an Ask Systems that could be used by instructors in many ways. We pushed the envelope about as far as possible in that culture. 


\section{How many doctoral and master's theses have you supervised?}

Only a few master's theses but I have supervised 27 doctoral dissertations with students from several countries. Supervising dissertations is perhaps the greatest honor for a professor.

\section{What are your fundamental conclusions regarding the role of technology in education?}

People do not learn from technology; they learn from thinking. When technologies can enhance students thinking, they should be used. Otherwise, they are probably no better than no technology.

\section{Who made the greatest influence on you as an academic?}

Early on, I followed Dave Merrill's theory development. His is perhaps the most coherent model of direct instruction. After focusing in constructivism, I moved in a different direction. As a researcher, I have always been impressed by the work of Gavriel Salomon. He is a gifted researcher. Also, I admire the work of Deanna Kuhn on argumentation.

\section{What are your major accomplishments and failures in retrospective?}

I suppose that my publications are my greatest accomplishment. I have received numerous publication and service awards for my contributions to the field. I am honored by them. The acknowledgement of your peers is perhaps the greatest honor that one can receive. I tell people all of the time that I have committed my share of mistakes in my personal life but career choice was not one of them. I cannot imagine any career that would have provided greater autonomy and also reward that the professoriate.

\section{How do you see the future of instructional design and technology field?}

It continues to be driven by technology (nowadays mobile technologies, games, etc.). While these are powerful technologies, I believe that researchers and designers should always focus first on the learning. Better understanding learning is essential to good design. I tell my students all of the time that if you are unable to articulate how you expect your learners to think, then you have no business designing instruction for them. Our field seems compelled by each new technology, as if it will somehow change the course of learning.

\section{What do you suggest to young colleagues in the field of educational technology?}

Find an issue that really impels you, and then carve out significant blocks of time to work on it. Perhaps more importantly, you should always take your work seriously but try not to take yourself too seriously.

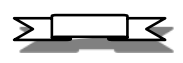

For manycolleagues, Professor Jonassen is perhaps one of the most admirable academics in the field of educational technology for a number of reasons. As seen repeatedly in his responses to our questions, he is not unidirectional in his thinking but has concurrent and multiple points of views. There is a saying in Anatolia which goes "One brain is not enough to understand the world." When you talk with or listen to Professor Jonassen, you may feel that he has several 
brains functioning simultaneously. I had this feeling many times when I had conversations with him. He is a conscientious academic who works fast, produces milestone work, offers sound alternatives, and assures quality. He is considered both critical and radical; however, he always provides liable alternatives in the areas he has dealt with.

In this interview Professor Jonassen has clearly emphasized that it is the learning not the technology that instructional designers should focus on. We should encourage student thinking with alternative perspectives rather than conveying information to them or providing learners with limited exposure to the unlimited world of knowledge. Therefore, the field of educational technology should not be perceived as the testing ground for every new technology as they emerge. We know that technology does not generate learning but it has a mediating role when the context is appropriate so that instructional designers should be eager to create the most nurturing environment for all learners. I think this has been the fundamental challenge for our field and Professor Jonassen has provided rigorous alternatives over the years both in theory and practice.

Correspondence: Ali Simsek, Professor, Institute of Communication Sciences, Anadolu University, Yunus Emre Campus, Eskisehir, Turkey 